\title{
Asymmetric Effect in the Relationship between Oil Prices and Activity: An Estimate of the VECM Model for Eight Emerging Countries
}

\author{
Mouldi Djelassi \\ School of Economics and Business Sciences of Tunis, University of Tunis, Tunisia \\ E-mail: jelassi196311963@gmail.com \\ Mdalla Omrani \\ Department of Economics, Faculty of Economics and Management of Tunis \\ University Tunis elManar, Tunisia \\ E-mail: omrani.mdalla@gmail.com
}

Received: March 10, 2019 Accepted: March 22, 2019 Published: May 12, 2019

doi:10.5296/ber.v9i2.14777～URL: https://doi.org/10.5296/ber.v9i2.14777

\begin{abstract}
In this study, we attempt to study the impact of oil shocks on the economic activity of eight emerging countries with different importing and exporting profiles, targeting and non-targeting inflation and thus verify the hypothesis of non-linearity. To do this, we used the VECM methodology. In addition to oil prices (the linear variation and its volatility, positive and negative movements in prices), we introduced the interest rate and industrial production as a proxy variable of the activity. The result shows that the economies of these countries are generally more sensitive to net increases in oil prices than to their volatility. Thus, the asymmetrical impact is clearly proven in the results especially in the long run. If the rise in oil prices negatively affects production, the decline does not favor its reshuffle. Indeed, if increases in oil prices reduce economic growth, their declines have no expansionary effect. In addition, the distinction between exporting and importing countries is not obvious. Furthermore, the addition of interest rates indicates that the first prefigurations indicate a tightening of interest rates by the central banks of the target and non-target countries selected in our study.
\end{abstract}

Keywords: Oil prices, VECM, Nonlinearity, Emerging country 
JEL Codes: Q43, C32, C22

\section{Introduction}

The question of the relationship between fluctuating oil prices and economic activity occupied the international scene more than 50 years ago. Since the two spectacular oil shocks of the 1970s, economists were already worried about the rapid rise in oil prices and its negative impact on economic growth. In fact, In fact, this subject has been treated very well and has attracted a considerable degree of attention for many decades.

For this reason, we focus in this study on the desirability of these cause-and-effect relationships between oil prices and the economic activity of eight target and non-targeting emerging countries, which have different profiles as exporters and importers of oil. The VECM methodology applied to monthly data was used to investigate the causal relationships between oil price fluctuations and the following macroeconomic variables: the industrial production and the interest rate. The first objective to be followed is to test the existence of an asymmetrical relationship between prices and economic activity. We will therefore see the reaction of industrial production to an innovation shock on the various indicators of oil prices. From the result found, we will also be able to assess the difference in the sensitivity of economies to oil shocks. The second objective is to observe and compare the various monetary responses between oil exporting and importing countries, targeting and non-targeting inflation. By looking at the interest rate responses to the same shocks, we can see the first intuitions about the reaction of the monetary authorities to the oil shock and to compare, thus, this reaction between targeting and non-targeting countries.

\section{Brief Description of Energy Sector in Emerging Countries, Subject of Our Study}

Our sample includes both oil exporting countries (Mexico, Argentina, Indonesia) as well as net importers (South Korea, Turkey, India, Tunisia, Czech Republic). In this section, we will present the characteristics of the energy sector in these countries.

\subsection{The Energy Sector in South Korea}

The energy sector holds a major place in South Korea and plays a leading role in the country's economy and in global markets. Because of its lack of national oil reserves, South Korea is a major importer of energy, importing virtually all of its oil requirements and it is the second largest importer of liquefied natural gas in the world behind Japan, the third largest importer of coal, and the fifth largest importer of crude oil. As South Korea is entirely dependent on imports, energy security in this country is very low. Total primary energy consumption, which was 43.9 million tones of equivalent (toe) in 1980, increased more than six times to 275.7000 toe in 2014, which ranked Korea the 10th largest energy-consuming nation in the world. The oil industry has been considered the basis of the South Korean industry because it is very important to provide the petrol sources that are necessary for the nation's economy. However, South Korea relies entirely on imports due to lack of oil resources. In 2014, for example, South Korea consumed nearly 2.4 million barrels per day (b / d) of oil. 
However, over the last few decades, the country has experienced development of the oil refinery industry. Indeed, most of South Korea's total oil production of $79.000 \mathrm{bpd}$ is based on refinery processing gains and a small amount of biofuel production. Indeed, Korea is a non-oil-producing country, relying entirely on imports to meet its crude oil requirements. Nevertheless this country is, currently known as a large exporter of petroleum products such as gasoline, diesel and kerosene.

\subsection{The Energy Sector in Turkey}

As a fast-growing country, Turkey's energy consumption has obviously increased. With insufficient hydrocarbon resources, the country relies heavily on the outside. According to the Economist Intelligence Unit (EIU), energy demand in Turkey will increase at an annual rate of $4.5 \%$ until 2017 in line with the expected growth in GDP. Energy in Turkey was mainly supplied by fossil fuels (petroleum, coal, natural gas, etc.), which are imported to $84 \%$. Official statistics from the Turkish Ministry of Energy and Resources announce that with sustained economic growth, oil consumption will increase at an increasingly progressive pace, reaching $64 \mathrm{Mt}$ in 2020. In parallel with this increase in the oil demand, the production stagnated and then declined remarkably. Indeed, due to the depletion of the deposits, this production is expected to be only $0.6 \mathrm{Mt}$ in 2020.

On the other hand, the growing demand for fuel and oil products combined with a rapidly expanding petrochemical sector is driving growth in Turkey's refining industry. Indeed, this country has become a leader in the hydrocarbon refining industry. In fact oil companies like "BP-Amoco", "Exxon-Mobil", "Shell”, "Total", "Gas de France", "Schlumberger" and "Chevron" are all located in Turkey to explore and to refine the oil mainly located in the south-east of the country. The refineries have a vacuum distillation capacity of about $210 \mathrm{~kb} /$ $\mathrm{d}$, which can treat the residue under vacuum or vacuum gas oil.

\subsection{The Energy Sector in Argentina}

Argentina is the third largest hydrocarbon producing country in Latin America, behind Mexico and Venezuela. Indeed, this country is an important player on the world energy market. According to the BP statistical Energy Survey (2009), Argentina had proven petroleum reserves of 2.586 billion barrels $(0.2 \%$ of the world's reserves) and natural gas reserves of 0.44 billion of cubic meters $(0.24 \%$ of the world total). With these enormous reserves, Argentina is ranked 4th after Mexico, Venezuela and Brazil. It is rapidly developing into a major producer and exporter of energy, accounting for about $14 \%$ of hydrocarbon production in Latin America in the 2000s. Oil accounts for more than half (51.5\%) of Supply of primary energy in Argentina, while natural gas is the next largest source of energy, accounting for nearly $40 \%$.

The International Energy Agency (2010) also reported that oil consumption in the country increased by an average of 491.73 thousand barrels of oil per day from the year $2009(0.59 \%$ of the world total), and 44, 1 billion cubic meters of natural gas, (1.5\% of the world total). In addition to oil production, the oil refining industry has seen a spectacular development in Argentina. In 2010, The REPSOL-YPF oil company dominates the downstream petroleum 
industry in Argentina, accounting for about half of the country's total crude oil refining capacity of $625,000 \mathrm{bpd}$.

\subsection{The Energy Sector in Mexico}

The energy sector in Mexico is based on non-renewable resources. Oil is the major source of fossil fuels in the country. Mexico is one of the largest producers of oil and other liquids in the world. Indeed, Mexico is the sixth largest oil producer in the world, with 3,700,000 barrels per day $(590,000 \mathrm{~m} 3 / \mathrm{d})$.

Although the petroleum industry is still relevant to the Mexican government budget because of its importance in GDP, exports have been steadily declining since the 1980s. In 1980, oil exports accounted for $61.6 \%$ of total exports, but in 2011, it was only 5.3\%. Despite its profile as a major exporter of crude oil, Mexico is a net importer of refined petroleum products. According to PEMEX, the country imported 641.000 bpd of refined petroleum products in 2016 (58\% of which was gasoline, and most of the remainder was diesel and liquefied petroleum gas (LPG)). Over the past 10 years, crude oil production has declined steadily, to record a decline of nearly 1 million barrels per day (bpd). Due to the decline in the production of the Cantarell deposit, crude oil production declined significantly between the mid-2000s and 2012.

If it wishes to maintain its position as an oil exporter, the country will have to make a major effort not only in hydrocarbon exploration and production but also in energy efficiency to cope with a growing domestic demand for oil and gas in recent years.

\subsection{The Energy Sector in India}

India is a net importer of energy. The supply of commercial energy in India is largely dependent on fossil energies. According to the International Energy Agency, fossil fuels accounted for $73 \%$ of the primary energy supply in India in 2010/2011. Its oil production is very low compared to its huge population and its strong economic growth. The production of oil and gas accounts for $23 \%$ and $63 \%$ respectively in 2016. On the other hand, the oil consumption in this country has been increasingly increased to meet the demands of economic growth. As a result, India is the fourth largest consumer of energy in the world after the USA, China, and Japan. A large part of these oil products is used to produce electricity. In fact, the electricity sector is a main item in India.

In terms of renewable energy, India estimated a potential renewable energy of 90.313 MW in 2010. However, much of this potential remains untapped and renewable energy accounts for only $1.65 \%$ in total primary energy supply. The production of electricity from renewable sources of energy such as nuclear, wind and solar energy represents only $1.63 \%$ or 8.96 Mtoe.

\subsection{The Energy Sector in Tunisia}

In recent years, Tunisia has seen an increase in energy demand which has led to a drain on energy resources and an increase in greenhouse gas emissions. Indeed, energy demand has increased by $5 \%$ per year since the late 1990s. The energy sector is characterized by a high dependence on fossil fuels. The consumption of energy comes mainly from two 
non-renewable resources that are respectively gasoline and natural gas. Since the 2000s, Tunisia has become a notable importer of energy. Renewable energy can no longer replace oil and other energy products that are increasingly expensive. Indeed, primary energy consumption in Tunisia has grown steadily with a rapid pace reflecting economic and social development. It increases at a rapid rate reaching 7947 Ktoe in 2010. The structure of energy consumption has been dominated by petroleum products which represent on average $65 \%$ of the total primary energy consumption. On the other hand, national oil production fell by $13.3 \%$ between 2009 and 2015, from 81.000 to 55.000 barrels per day, resulting in a deficit of 4 million tons of supply.

Natural gas has gradually surpassed oil as the dominant fuel of Tunisia. By 2019, more than $54 \%$ of Tunisia's gas needs were imported from Algeria, compared to 51\% in 2014. Between 1990 and 2014, the share of natural gas in the country rose from $28 \%$ to $55 \%$, while the share of oil fell from $72 \%$ to $45 \%$. The majority of Tunisia's gas needs are imported from Algeria.. The increase in domestic consumption levels is explained, in part, by an increase in energy subsidies, which account for about 5\% of Tunisia's overall GDP in 2016.

\subsection{The Energy Sector in Indonesia}

The energy sector in Indonesia is mainly based on coal production (61\%), natural gas (14\%), biomass (12.2\%) and oil (9.5\%). The economic recovery of the country after the 1997/1998 crisis contributed to increased demand for fuel, which led the government to leave OPEC due to the growing import of hydrocarbons. According to Indonesian statics, Indonesia's total primary energy consumption increased by $43 \%$ between 2003 and 2013, the country's share of oil, although declining, still accounts for the largest share of Indonesia's energy mix at 38\% in 2013.

Beginning in the 1990s, Indonesia's crude oil production declined steadily due to lack of exploration and investment in the sector. In recent years, the weakening of the country's oil sector has effectively hampered national GDP growth. The decline in Indonesia's oil production in combination with increased domestic demand turned Indonesia into a net importer of oil from 2004, resulted in her leaving from the OPEC in 2009 and ending its long-term membership (1962-2008) in the organization. However, since the discovery of new deposits such as the Jangkrik deposit, the oil production has increased in the country and Indonesia joined OPEC again in December 2015.

\subsection{The Energy Sector in Czech Republic}

The Czech Republic is an energetically dependent country; it is a net importer of energy. Indeed, it is not a major energy producer and it does not have large energy reserves. In fact, the energy consumption in this country is largely based on fossil fuels, including coal and gas products (with a $40 \%$ share in the energy mix). Concerning oil, the Czech Republic has minor oil resources. In 2000, oil production (including natural gas liquids, other liquids, and refinery gains) averaged 4.000 barrels per day ( $\mathrm{b} / \mathrm{d}$ ), while crude oil and petroleum products averaged about 187.000 (b / d). The future national oil production is estimated to remain essentially constant. Local production covers only a very small fraction of demand in the 
Czech Republic. In 2012, 176.000 tons of crude oil were extracted locally while 5.997000 tons were imported (Most of the oil imports come from the Russian Federation, the Middle East and Germany).

According to Eurostat, the Czech Republic's rate of energy and especially petroleum dependence has declined in recent years. This is due to the country's inclusion in well-defined and diversified long-term strategic energy efficiency programs and the growing role of renewable energies (solar, wind ...). According to Eurostat, the share of renewable energies reached $11.2 \%$ in 2016 , mainly due to solar and hydroelectric contributions in electricity generation.

\section{Evaluation of the Impact of Petroleum Prices on Economic Activity: an Error Correction Vector Modeling (VECM)}

In this study, we examine the sensitivity of eight emerging countries to changes in oil prices using the VECM methodology. Our investigation is based on monthly data covering the period from 1986M1 to 2013M12 for South Korea, India and Mexico, from 1986M4 to 2016M12 for Turkey, from 1986M3 to 2013M12 for Indonesia ${ }^{1}$, from 1987M1 to 2013 M12 for Argentina and finally from 1993M1 to 2013M12 for the Czech Republic and Tunisia. Stationary and cointegrating techniques were then used to identify the relationship between variations in oil prices and their volatility, as well as the positive and negative movements of the same prices and two macroeconomic variables that are explicitly, the interest rate and the industrial output. The latter is considered a "proxy" variable of economic activity.

The oil price series is derived from the basis of the Energy Information Administration. The series we use in our work is the real price of the West Texas Intermediate (WTI). This type of oil was chosen because the majority of the selected countries imports and exports this kind of oil. It is none other than the ratio between the world price of oil corrected by the bilateral exchange rate of each country and deflated by the index of consumer prices. We therefore propose to explore four transformations of oil prices that are respectively: linear variations ${ }^{2}$ (or oil), asymmetric variations (oilpos), (oilneg) ${ }^{3}$, and relative increases in oil prices (volatility or scaled prices) ${ }^{4}$. The Consumer Price Index, the exchange rate, and the nominal short-term interest rate $^{5}$ come from the IMF, IFS (International Financial Statistic) base. In case of missing data, they are supplemented by the OECD database (Main Economic Indicators).

\footnotetext{
${ }^{1}$ Since 2008, Indonesia has changed status to become a net oil importer because of the dramatic fall in oil production. Nevertheless, by the end of 2012, the discovery of new deposits in the south of the country has massively boosted oil production. As a result, we have considered Indonesia as an exporter of crude over the entire period of our empirical investigation.

${ }^{2}$ This price indicator is measured as follows : $\Delta$ oil $=\left(\ln\right.$ oil $\mathrm{t}-\ln$ oil $\left.\mathrm{t}_{\mathrm{t}-1}\right)$

${ }^{3}$ This price indicator is measured as follows : $\left(\Delta\right.$ oil $\left._{\mathrm{t}+}\right)=\max \left(0,\left(\Delta\right.\right.$ oil $\left._{\mathrm{t}}\right)$ and $\left(\Delta \mathrm{oil}_{\mathrm{t}-}\right)=\min \left(0,\left(\Delta \mathrm{oil}_{\mathrm{t}}\right)\right.$

${ }^{4}$ This variable is estimated by estimating a GARCH model.

${ }^{5}$ The short-term nominal interest rate is used to calculate the real interest rate. The latter is none other than the difference between the nominal interest rate and the rate of inflation calculated through the Consumer Price Index (CPI).
} 


\subsection{Stationarity Test}

In this part of the empirical study, we used the Augmented Dickey-Fuller unit root (ADF) test and the Phillips-Perron test to explore the nature of the series while considering the null hypothesis that all series have a unit root (non-stationary) versus the alternative that the series have no unit root (stationary).

Tested in level, we found that all series are non-stationary. It is therefore important to verify the stationarity of the variables by differentiating them. The series have become stationary in first difference. They are all integrated in the same order I (1) (Engle (1982), Engle and Granger, 1987), which makes it necessary to use the cointegrating test to study the long-term relationship between the series, object of our empirical work.

The test results for Phillips-Perron are reported in the appendix 1. The standard unit root test results for $\mathrm{ADF}$ for each model are shown in the following tables:

Table 1. Level ADF test in the case of oil price volatility

\begin{tabular}{|l|l|l|l|l|l|l|l|l|l|}
\hline & Mexico & Argentina & India & South korea & Indonesia & Tunisia & Czech Republic & Turkey & C.V*at $1 \%, 5 \%, 10 \%$ \\
\hline IPI & $-1,5784$ & $-1,7253$ & $-1,4452$ & $-1,9732$ & $-1,9560$ & $-1,6460$ & $-1,2528$ & $-2,0674$ & $-2,869952$ \\
& & & & & & & & & $-2,571321$ \\
\hline
\end{tabular}

* Critical Value.

Table 2. ADF test in first difference in the case of volatility of oil prices

\begin{tabular}{|l|l|l|l|l|l|l|l|l|l|}
\hline & Mexico & Argentina & India & South korea & Indonesia & Tunisia & Czech Republic & Turkey & $\begin{array}{l}\text { C.V* at } \\
\mathbf{1 \%}, \mathbf{5 \%}, \mathbf{1 0 \%}\end{array}$ \\
\hline IPI & $-11,6830$ & $-3,4931$ & $-4,1985$ & $-4,7589$ & $-19,2295$ & $-4,7069$ & $-14,08701$ & $-23,1720$ & $\begin{array}{l}-3,450682 \\
-2,870387 \\
-2,571554\end{array}$ \\
\hline IR & $-5,4408$ & $-11,4734$ & $-12,3683$ & $-15,0563$ & $-13,4208$ & $-13,5809$ & $-13,8769$ & $-14,0856$ & $-2,870387$ \\
\hline & & & & & & & & & $-2,571554$ \\
\hline
\end{tabular}

* Critical Value. 
Table 3. ADF level test in the case of the variations in oil prices

\begin{tabular}{|l|l|l|l|l|l|l|l|l|l|}
\hline & Mexico & Argentina & India & South korea & Indonesia & Tunisia & Czech Republic & Turkey & C.V*at 1\%,5\%,10\% \\
\hline IPI & $-1,5784$ & $-1,7253$ & $-1,4452$ & $-1,9732$ & $-1,9560$ & $-1,6460$ & $-1,2528$ & $-2,0674$ & $-2,869952$ \\
& & & & & & & & $-2,571321$ \\
\hline
\end{tabular}

* Critical Value.

Table 4. ADF test in first difference in the case of the variation in oil prices

\begin{tabular}{|l|l|l|l|l|l|l|l|l|l|}
\hline & Mexico & Argentina & India & South korea & Indonesia & Tunisia & Czech Republic & Turkey & $\begin{array}{l}\text { C.V*at } \\
\mathbf{1 \%}, \mathbf{5 \%}, \mathbf{1 0 \%}\end{array}$ \\
\hline IPI & $-11,6830$ & $-3,4931$ & $-4,1985$ & $-4,7589$ & $-19,2295$ & $-4,7069$ & $-14,0870$ & $-23,1720$ & $\begin{array}{l}-3,450682 \\
-2,870387 \\
-2,571554\end{array}$ \\
\hline IR & $-5,4408$ & $-11,4734$ & $-12,3683$ & $-15,0563$ & $-13,4208$ & $-13,5809$ & $-13,8769$ & $-14,0856$ & $-3,450682$ \\
$-2,870387$ \\
OIL & $-15,5325$ & $-12,3631$ & $-16,6683$ & $-14,4723$ & $-15,5325$ & $-12,3631$ & $-15,4229$ & $-12,3631$ & $-2,871554$ \\
\hline
\end{tabular}

* Critical Value.

Table 5. Level ADF test in asymmetric case

\begin{tabular}{|l|l|l|l|l|l|l|l|l|l|}
\hline & Mexico & Argentina & India & South korea & Indonesia & Tunisia & Czech Republic & Turkey & $\begin{array}{l}\text { C.V* at } \\
\mathbf{1 \%} \mathbf{5 \%}, \mathbf{1 0 \%}\end{array}$ \\
\hline IPI & $-1,5784$ & $-1,7253$ & $-1,4452$ & $-1,9732$ & $-1,9560$ & $-1,6460$ & $-1,2528$ & $-2,0674$ & $\begin{array}{l}-3,449679 \\
-2,869952\end{array}$ \\
\hline IR & $-2,1270$ & $-1,3438$ & $-1,6039$ & $-1,9899$ & $-2,2728$ & $-2,2479$ & $-0,9675$ & $-2,3461$ & $-2,869952$ \\
\hline & & & & & & & & & $-2,571321$ \\
\hline
\end{tabular}

* Critical Value. 
Table 6. ADF test in first difference in the asymmetric case

\begin{tabular}{|l|l|l|l|l|l|l|l|l|l|}
\hline & Mexico & Argentina & India & South korea & Indonesia & Tunisia & Czech Republic & Turkey & $\begin{array}{l}\text { C.V* at } \\
\mathbf{1 \% , 5 \% , 1 0 \%}\end{array}$ \\
\hline IPI & $-11,6830$ & $-3,4931$ & $-4,1985$ & $-4,7589$ & $-19,2295$ & $-4,7069$ & $-14,0870$ & $-23,1720$ & $\begin{array}{l}-3,450682 \\
-2,870387 \\
-2,571554\end{array}$ \\
\hline IR & $-5,4408$ & $-11,4734$ & $-12,368$ & $-15,0563$ & $-13,4208$ & $-13,5809$ & $-13,8769$ & $-14,0856$ & $-2,870387$ \\
\hline & & & & & & & & & \\
\hline
\end{tabular}

* Critical Value.

\subsection{Coin- integration Test}

The choice of the VECM methodology is necessary because it makes it possible to distinguish between two dynamics (short and long term) and also includes a correction aspect called the error term correction coefficient (ECT). In fact, the essence of VECM lies in the implication that the series of the study are categorized, which implies the existence of the long-term relations6. So, we carried out the cointegration test which is based on the two statistical tests proposed by Johannsen (1991): the trace test and the maximum eigenvalue test. We used both of these tests to make a comparison of the results.

The trace test indicates that there is only one cointegration relationship for all the countries studied, while the maximum eigenvalue test indicates that there is more than a cointegrating relationship in some countries such as Czech Republic and South Korea in the model which deals with the estimation of oil volatility. Once this step is completed, we approach the estimation of the model.

The results of our tests are displayed in the tables below:

Table 7. Trace test result in the case of price variation

\begin{tabular}{|l|l|l|l|l|l|l|l|l|l|}
\hline & Mexico & Argentina & India & South korea & Indonesia & Tunisia & Czech Republic & Turkey & C.V* at 5\% \\
\hline r=0 & 88,94410 & 92,13468 & 76,99406 & 34,75325 & 63,69366 & 46,99081 & 73,01805 & 216,0626 & 29,79707 \\
\hline $\mathbf{r = 1}$ & 6,571146 & 8,803860 & 13,16731 & 6,526534 & 4,881132 & 8,831759 & 14,62547 & 8,719536 & 15,49471 \\
\hline $\mathbf{r = 2}$ & 2,596859 & 0,776260 & 2,532732 & 2,468843 & 0,926931 & 2,687375 & 4,324325 & 1,341560 & 3,841466 \\
\hline
\end{tabular}

* Critical Value.

\footnotetext{
${ }^{6}$ In the statistics, the presence of cointegration between the variables indicates that a linear combination of non-stationary time series presents a stationary series. As a result, the error correction mechanism is integrated in the model to determine the variations associated with the adjustment of a long-term relationship.
} 
Table 8. Maximum eigenvalue test result in the case of the variation of the courses

\begin{tabular}{|c|c|c|c|c|c|c|c|c|c|}
\hline & Mexico & Argentina & India & South korea & Indonesia & Tunisia & Czech Republic & Turkey & C.V* at 5\% \\
\hline $\mathbf{r = 0}$ & 82,37295 & 83,33082 & 63,82675 & 54,59022 & 58,81253 & 38,15905 & 58,39258 & 207,3430 & 21,13162 \\
\hline $\mathbf{r = 1}$ & 3,974287 & 8,027600 & 10,63457 & 11,04784 & 3,954201 & 6,144384 & 10,30115 & 7,377976 & 14,26460 \\
\hline $\mathbf{r = 2}$ & 2,596859 & 0,776260 & 2,532732 & 2,468843 & 0,926931 & 2,687375 & 4,324325 & 1,341560 & 3,841466 \\
\hline
\end{tabular}

* Critical Value.

Table 9. Trace test result in the case of price volatility

\begin{tabular}{|c|c|c|c|c|c|c|c|c|c|}
\hline & Mexico & Argentina & India & South korea & Indonesia & Tunisia & Czech Republic & Turkey & C.V* at 5\% \\
\hline r=0 & 82,17880 & 26,91380 & 69,45318 & 20,8934 & 46,49807 & 47,37493 & 46,49807 & 60,87447 & 21,13162 \\
\hline $\mathbf{r = 1}$ & 10,16581 & 11,92470 & 8,446042 & 16,65721 & 5,321145 & 5,072373 & 4,681672 & 5,072373 & 14,26460 \\
\hline $\mathbf{r = 2}$ & 2,773204 & 1,839454 & 2,388281 & 6,045467 & 0,025114 & 5,045467 & 1,108992 & 1,568586 & 3,841466 \\
\hline
\end{tabular}

* Critical Value.

Table 10. Trace test result in asymmetric case

\begin{tabular}{|c|c|c|c|c|c|c|c|c|c|}
\hline & Mexico & Argentina & India & South korea & Indonesia & Tunisia & Czech Republic & Turkey & C.V*at 5\% \\
\hline $\mathbf{r = 0}$ & 112,2171 & 96,53671 & 83,76708 & 74,82423 & 63,16131 & 61,06855 & 80,44451 & 333,8195 & 47,85613 \\
\hline $\mathbf{r = 1}$ & 22,51599 & 35,52602 & 28,15484 & 15,19685 & 17,14375 & 20,56965 & 19,88904 & 18,02718 & 29,79707 \\
\hline $\mathbf{r = 2}$ & 3,836195 & 9,563168 & 11,1648439 & 7,829234 & 7,653519 & 6,526555 & 5,397967 & 8,227934 & 15,49471 \\
\hline $\mathbf{r = 3}$ & 0,306540 & 3,303518 & 1,199930 & 2,775206 & 2,786479 & 3,599424 & 1,867560 & 0,658320 & 3,841466 \\
\hline
\end{tabular}

* Critical Value.

Table 11. Maximum eigenvalue test result in the asymmetric case

\begin{tabular}{|c|c|c|c|c|c|c|c|c|c|}
\hline & Mexico & Argentina & India & South korea & Indonesia & Tunisia & Czech Republic & Turkey & C.V* at 5\% \\
\hline $\mathbf{r = 0}$ & 81,70109 & 28,39974 & 55,61225 & 108,0654 & 46,01756 & 91,76418 & 60,55547 & 315,7923 & 27,58434 \\
\hline $\mathbf{r = 1}$ & 18,67979 & 2,071129 & 6,47044 & 7,367619 & 9,490233 & 22,69563 & 14,49107 & 9,799251 & 21,13162 \\
\hline $\mathbf{r = 2}$ & 3,529655 & 1,570309 & 10,48446 & 5,054028 & 4,867040 & 10,12598 & 3,530406 & 7,569614 & 14,26460 \\
\hline $\mathbf{r = 3}$ & 0,306540 & 3,303518 & 1,199930 & 2,775206 & 2,786479 & 3,599424 & 1,867560 & 0,658320 & 3,841466 \\
\hline
\end{tabular}

* Critical Value.

\subsection{Results of the Estimates by the VECM Model}

We applied the VECM estimate both for the linear and non-linear measurement of oil price shocks as well as the measure of price fluctuations and their volatility.

The general model considered is an autoregressive vector model (VAR) composed of the following variables:

$$
\mathrm{i}_{\mathrm{t}}=\mathrm{A}_{\mathrm{i} 1} \mathrm{X}_{\mathrm{it}-1}+\mathrm{A}_{\mathrm{i} 2} \mathrm{X}_{\text {it- } 2}+\ldots . .+\mathrm{A}_{\text {ip }} \mathrm{X}_{\text {it-p }}+\varepsilon_{\mathrm{it}}
$$

With $\mathrm{X}_{\mathrm{it}}=$ (index of industrial production, real oil price, real interest rate).

$\mathrm{A}_{\mathrm{ij}}=$ the matrix of the coefficients and $\varepsilon i \mathrm{t}=$ the vector of the errors. We write equation (2) in the form of a VECM model:

$$
\begin{gathered}
\Delta X i t=\Gamma_{1} \Delta X i_{t-1}+\Gamma_{2} \quad \Delta X_{i t-2}+\ldots \ldots+\Gamma P \quad \Delta X_{i t-p+1}+\alpha \Pi X_{i t-1}+\varepsilon_{i t} \\
\text { With } \Pi=A_{1}+A_{2}+\ldots \ldots \ldots \ldots+A_{K-1}
\end{gathered}
$$




\subsubsection{Interpretation of the Short-term Block}

Our analyzes cover both the cumulative response functions of industrial production and the interest rate arising from a shock on oil prices, as well as the error term coefficient study, also called the velocity vector for the return to equilibrium The error term coefficient appears negative and statistically significant ${ }^{7}$. Our coefficients in this estimate have values consistent with those expected. The results are reported in Appendix 2.

\subsubsection{Impact on Industrial Production}

We will begin our interpretation by analyzing the reaction of industrial production to an innovation shock on the various indicators of oil prices. We will analyze the cumulative responses at 6 months, 12 months and 18 months.

\section{a) - Interpretation of the simulation of a shock on the oil price's volatility:}

First, it should be noted that the difference between exporting and importing countries is not very clear according to the results. In fact, this point deserves to be emphasized, because the results are in many cases paradoxical. A shock on price volatility does not cause a significant contraction of the industrial production in importing countries. Conversely, we see that price volatility generates positive effects in the Czech Republic and Tunisia while we expected a negative response. For the rest of the importing countries, the result confirms the theoretical predictions. There is also a negative impact of oil price volatility on the activity of the Indian, Turkish and Korean economies. India and Turkey are the most affected, India to a large extent. In the case of South Korea, a net oil importing country, the response is reduced compared to other importing countries chosen in our model. This low effect is reflected in the decrease in energy consumption in this country and in its use of nuclear and hydraulic energy, which have limited its oil needs.

Taking the case of oil exporting countries, our results indicate that the response of Mexico and Indonesia to the price innovation shock is positive. Nevertheless, the Latin American country seems to be benefiting to a greater extent. Given their net oil exporter profile, Mexico and Indonesia benefit in the short term from a positive demand shock due to higher incomes. For Indonesia, which is a member of OPEC, her wealth depends to a large extent on the revenues derived from oil exports. In the end of 2008 and after several decades exporting, Indonesia began importing oil. Nevertheless, the pace of the decline in domestic oil production has been followed by a very moderate increase in energy imports. It then appears that the volatility of oil prices has not largely affected economic activity in this country by looking at its constant domestic consumption.

In the case of Argentina, which is also a crude exporting country, the result is surprising. The Latin American country does not seem to have gained from the fluctuation of oil prices in the short term. This stagnation of short-term activity can also be explained by the phenomenon of

\footnotetext{
${ }^{7}$ Indonesia and the Czech Republic have the highest error coefficient coefficient compared to other countries. Indeed, for Indonesia, the speed of adjustment of the variables towards the long-term target in the model introducing the linear variations is $-0,62 \%$ and $-0,14 \%$ in the case of asymmetric oil prices. While, for the Czech Republic, the speed of the deviation of the variables corresponds to $-0,29 \%$ in the model of the oil volatility.
} 
deutsche syndrome (deutsche disease). In fact, the endowment of natural resources such as oil generates an increase in national income and consequently increases demand, which in turn increases inflationary pressures. The other sectors of the economy are then neglected and they are not able to generate added value to replace losses in the oil sector, which causes a stagnation of economic activity even in the short term.

\section{b) Interpretation of the simulation of a price change shock :( linear prices)}

Compared with the indicator of oil price volatility, the pace of impulse functions remains the same except for India, Tunisia, Turkey, the Czech Republic and Indonesia, all of which are within their respective importer groups (India, Turkey and the Czech Republic) and exporter (Indonesia). India has become much less resilient to a shock on price movements. According to Blanchard and Jordini (2007), the oil shock decreases the profitability of the industry sector of oil-importing countries such as India, which causes a change in the medium-long-term productive structure in the oil-importing as a result of the reallocation of production factors. Indeed, capital and labor are turning away from other sectors that are less sensitive to oil shocks. As a result, there is a decline in the profitability of producers and investors in these sectors, which negatively affects the rate of economic growth. For Turkey, the result is surprising. This country benefits from the linear variation in oil prices, but very slightly. It seems that for this Asian country the provisional perception of the shock has not favored a change in the behavior of economic agents in a short-term maturity. Indonesia's response shows an always positive response, but it is more important than the indicator of price volatility.

As regards Tunisia and the Czech Republic, these two countries continue to benefit, but less widely, compared to the oil volatility indicator. For the rest, Mexico's response is always positive by looking at its status as a net oil exporting country. For Argentina, the reaction has not changed given that its economic activity is negatively affected by the change in oil prices. This country still behaves as an importing country. South Korea's industrial output is still negatively affected by price fluctuations as long as oil volatility. The Korean economy seems to be more penalized by price fluctuation than the oil volatility indicator.

\section{c) Analysis of the impact of oil shocks on the interest rate: the first intuitions on the conduct of monetary policy:}

The expected impact on the interest rate depends on the objectives set by the central banks, which are generally divided into two visions: either a restrictive monetary policy that seeks price stability by combating inflationary pressures that can be triggered as a result of rising oil prices, an accommodative monetary policy aimed at reviving economic growth by keeping the level of production close to its potential level. From this perspective, we can expect positive interest rates in the first vision reflecting price stability and negative interest rates in the second vision explaining the preferences of the monetary authorities to counter the negative effects on production associated with supply shock.

Let us begin with the exporting countries, for Mexico and Indonesia, the monetary authorities seems to relax their monetary policy. The two countries show a response function that seems 
more neutral in order to cancel the demand effect linked to the temporary increase in income. In order to encourage investment in sectors other than the oil sector, the central banks of both countries reduce the interest rate aimed at stimulating activity, given that the investment remains a fundamental driver of economic growth ${ }^{8}$. In the case of Argentina, inflationary pressures induce the monetary authorities to raise the interest rate by applying a restrictive monetary policy.

For oil-importing countries, an inflationary oil shock pushes the monetary authorities to revive a restrictive monetary policy aimed at countering inflationary effects. Nevertheless, Tunisia and the Czech Republic show a negative response, in the case of price fluctuations and their volatility, which deviates from our expectations. Tunisia and especially the Czech Republic seem to consider the risk of inflation less and react less strongly. We can thus think of the thesis advanced by Lee et al (1995) and Ferderer (1996). These authors state that in the short term, an oil shock may appear momentary and transitory in the eyes of economic agents whom can leave their lifestyle and will not change their behavior ${ }^{9}$. The Korean, Turkish and Indian economy always opts for a restrictive monetary policy by raising the interest rate in the two regressions. For the model of oil volatility, the result shows a broaden interest rate response in Turkey compared to the other two countries. This country retains a special status since it is hardening its monetary positioning. This paradox can be interpreted as the desire to limit the recessionary effects in the regime of price variation, and to more firmly fight against inflationary pressure in the regime of price volatility.

The result of the estimate of the change in oil prices shows that, with the exception of the Czech Republic, Indonesia and Tunisia, the central banks of other emerging countries are fairly rigorous because the reaction of central banks appeared restrictive. The result does not distinguish between targeting and non-targeting countries and demonstrates that the major concern for these countries is the maintenance of price stability that may be threatened by an oil shock.

\subsubsection{Interpretation of the Long-term Block}

In the long term, the result we found is also mixed. Indeed, for some countries, industrial production is more affected by the variable of real oil price volatility and their variation, but for others the result seems unexpected. We will interpret the results of two models simultaneously to make a comparison.

The tables below represent the result of the estimation of the coefficients relative to the long-term dynamics:

\footnotetext{
${ }^{8}$ The Mexican bank opts for the second configuration (price variation) for a less accommodative monetary policy, so the answer becomes positive but it is minor.

${ }^{9}$ They believe that the oil shock has a temporary impact that will dissipate in the very short term and they therefore expect the stabilization of prices.
} 
Table 12. Estimation of the long-term block in the linear case

\begin{tabular}{|l|l|l|l|l|l|l|l|l|}
\hline & Mexico & Indonesia & Argentina & Turkey & $\begin{array}{l}\text { Czech } \\
\text { Republic }\end{array}$ & Tunisia & $\begin{array}{l}\text { South } \\
\text { Korea }\end{array}$ \\
\hline \multirow{2}{*}{ Oil(-1) } & $\begin{array}{l}-0,20242 * * * \\
{[0,07402]}\end{array}$ & $\begin{array}{l}0,22536 * \\
{[0,13516]}\end{array}$ & $\begin{array}{l}-0,185758 * * \\
{[0,07856]}\end{array}$ & $\begin{array}{l}-0,29082 * \\
{[0,17127]}\end{array}$ & $\begin{array}{l}-0,11981 * * * \\
{[0,03494] * *} \\
{[-7,89569]}\end{array}$ & $\begin{array}{l}-0,141052 * * \\
{[0,07706]}\end{array}$ & $\begin{array}{l}-0,34503 * * * \\
{[0,05502]}\end{array}$ & $\begin{array}{l}-0,20093 * * * \\
{[0,07774]} \\
{[0,07774]}\end{array}$ \\
\hline \multirow{2}{*}{$\mathbf{I R}(-\mathbf{1})$} & $\begin{array}{l}-0,275314 * * * \\
{[0,07258]}\end{array}$ & $\begin{array}{l}0,171578 * * \\
{[0,07160]}\end{array}$ & $\begin{array}{l}-0,194459 * * \\
{[0,09651]}\end{array}$ & $\begin{array}{l}-0,34080 * * * \\
{[0,06096]}\end{array}$ & $\begin{array}{l}-0,07551 * * \\
{[0,03658]}\end{array}$ & $\begin{array}{l}-0,131661 * * * \\
{[0,04574]}\end{array}$ & $\begin{array}{l}-0,28409 * * * \\
{[0,06527]}\end{array}$ & $\begin{array}{l}-0,2457 * * * \\
{[0,06452]}\end{array}$ \\
\hline
\end{tabular}

$*, * *, * * *$ indicate the level of significance at $1 \%, 5 \%, 10 \%$.

The values in braces represent the standard deviations of the coefficients.

Table 13. Estimation of the long-term block in the volatility case

\begin{tabular}{|l|l|l|l|l|l|l|l|l|}
\hline & Mexico & Indonesia & Argentina & Turkey & Czech Republic & Tunisia & India & South Korea \\
\hline VOL $(-\mathbf{1})$ & $-0,27700^{*}$ & $0,392350 * *$ & $-0,20488 * *$ & $-0,31303 * * *$ & $-0,13814 * * *$ & $-0,09743 * * *$ & $-0,40269 * *$ & $-0,27679 * * *$ \\
& {$[0,16435]$} & {$[0,06420]$} & {$[0,08556]$} & {$[0,07077]$} & {$[0,06374]$} & {$[0,01159]$} & {$[0,21042]$} & {$[0,07804]$} \\
\hline Ir $(-\mathbf{1})$ & $-0,19274 * * *$ & $0,283550 * *$ & $-0,175075 * *$ & $-0,25206 * * *$ & $-0,13167 * *$ & $-0,108799 * *$ & $-0,24600 * *$ & $-0,23458^{* *}$ \\
& {$[0,05438]$} & {$[2,92881]$} & {$[0,09629]$} & {$[0,06627]$} & {$[0,06995]$} & {$[0,06263]$} & {$[0,07726]$} & {$[0,11070]$} \\
\hline
\end{tabular}

$*, * *, * * *$ indicate the level of significance at $1 \%, 5 \%, 10 \%$.

The values in braces represent the standard deviations of the coefficients.

Based on the results, we found again that the separation between the exporting and the importing countries is not too obvious in the case of the simulation of the oil variation (model 1 ) and the simulation of the oil volatility (model 2 ).

Let's start with the oil-exporting countries; the result seems to be abrupt for Mexico. In fact, oil prices and interest rates are significant but they are negatively correlated with industrial production. The result is unexpected. Concerning Argentina, the negative effect of oil shocks in the short term continues to spread in the long term. However, the Mexican economy appears more penalized in the long term with the introduction of the measurement of oil volatility. With regard to the relationship between interest rates and industrial production; it seems to us that the result is perfectly logical for both countries. The increase in oil revenues of the two exporting countries accentuates the effect of demand. This behavior generates an excess of the domestic demand in the economy and a parallel increase in production. There is an increase in the general level of prices and an increase in inflationary risk (through the effect of the Consumer Price Index). The response of the monetary authorities in this case is to raise the interest rate by applying a restrictive monetary policy to counter inflationary pressures and ensure price stability. The result also confirms that the distinction between targeting and non-targeting countries is not clear since Argentina, a non-targeting country, reacts in the same way as Mexico.

For Indonesia, the third largest oil exporting country in the sample, we see that the volatility of oil prices and their variations have a positive and significant impact on industrial production. In the case of Indonesia, whose wealth depends mainly on income from the production and export of crude oil, the upward volatility of oil prices can be seen as a positive shock of impact because it leads to an increase in income and acts positively on the level of activity. As a result of this diversification of its industry, Indonesia has been able to absorb 
the undesirable effects of oil price volatility with greater success (Mehrara and Oskui, 2006) ${ }^{10}$.

Talking now about oil-importing countries, the results of the long-term block are in line with theoretical predictions. The increase in oil prices negatively affects economic activity and causes its contraction. It also appears that the countries (Tunisia and the Czech Republic) which have benefited in the short term from the rise in oil prices; they are penalized in the long term. In the case of the Czech Republic and India, we find that the interest rate variable always has the same negative impact on industrial production. Moreover, the result shows that India is the importing country most affected in the long term by fluctuations in oil prices. This reinforces the idea of the greater dependence of this Asian country on the fluctuations of oil which occupies a preponderant place in the Indian industry. Indeed, the structure of the Indian industry is based in a remarkable way on fossil fuels and, above all, on oil, which dominates Indian imports. The country ranks 3rd in the world rankings in terms of oil consumption after China and the United States. However, for the Czech Republic, in addition to oil, the country also relies heavily on nuclear and hydroelectric power (renewable energy) in the structure of its electricity industry ${ }^{11}$.

For South Korea and Turkey, the negative impact of the change in oil prices and their volatility on the economic activity of two countries is continuing. It is also noted that the impact of volatility is greater than the simple variation whose effect remains slightly ephemeral compared to the volatility indicator. Concerning the interest rate variable, our empirical estimate shows that the increasing in interest rates leads to a drop in production in Korea and Turkey respectively. According to the results, it is also noted that South Korea is affected to a lesser extent by fluctuations in prices compared with Turkey. This result is quite logical in looking at the structure of production in Turkey, whose energy needs are growing rapidly. In the electricity sector, Turkey uses massively gas (whose price is indexed to oil) to produce more than $43 \%$ of electricity. While in South Korea, there is massive use of nuclear power in the production of electricity. Indeed, the Korean economy is endowed with four nuclear power stations that have enormous production capacities and they are a good substitute for oil. In addition, Turkey is not as good in terms of energy efficiency in comparison with Korea. Indeed, South Korea reflects a gain in energy productivity ${ }^{12}$.

Finally, as far as Tunisia is concerned and contrary to the short-term relationship, observations of the results lead us to conclude that there is a change in the reaction of industrial production. In the long term, Tunisia has reacted like an importing economy. We see a contraction of its industrial production in both models. The reaction of the interest rate shows a restrictive behavior of the monetary policy of Tunisia. This result confirms that the

\footnotetext{
${ }^{10}$ The result we found went against some assertions that countries targeting inflation were "inflation nutter" because they're only concerned about inflation. Indeed, for the case of Indonesia, whose monetary policy is based on inflation targeting, the increase in oil revenues is prompting the monetary authorities and, more specifically, Banka Negara Indonesia (BNI ) to increase the interest rate.

${ }^{11}$ This central role of nuclear energy is confirmed by statistics representing a $33 \%$ rate devoted to the production of electricity.

${ }^{12}$ The Asian dragon experienced a decline in primary energy intensity which accelerated sharply to more than $27 \%$ in 2013.
} 
conduct of monetary policy is focused in the near future on the inflation targeting strategy and this according to the governor of the Tunisian central bank (BCT).

The analysis of the long-term dynamics shows a strong sensitivity of the economic activity of the importing countries and even the exporting countries to the oil shocks. Because of the importance of crude oil as one of the most important raw materials for the industrial production sector, any change in its price can directly affect the economic activity of a country. It appears that the profitability of the oil-consuming sectors is negatively impacted by the rise in crude oil prices, which modifies the productive structure of these sectors. This behavior has the effect of limiting demand (effect of demand) and ultimately reducing the rate of growth of economic activity.

\subsubsection{Interpretation of the Non-linear Impact of Oil Prices}

Using the same VECM methodology, we will try to test the existence of a nonlinear relation between oil prices and economic activity. Thus, with the non-linear specification and using the Mork transformation (1989), we have classified oil prices up and down and attempted to study their simultaneous impact on economic activity. The result of our empirical investigation shows that the asymmetric relation is verified only in the long term for the majority of the countries.

\subsubsection{Analysis of Short-term Dynamics}

The short-term outcome shows that the exporting countries, with the exception of Argentina, benefited from positive price movements, which resulted in a shift in output contracted somewhat in the case of lower prices. Indonesia and Mexico seems to benefit more from rising prices and less impacted by their declines. The price declines did not cause a significant decline in production, as the response is always positive by contracting only slightly. The interest rate response to both shocks is positive in Mexico. Indeed, it appears that the Mexican bank applies a restrictive monetary policy when prices fluctuate positively in order to absorb the inflationary pressures that can be created by the expenditure effect resulting from the reorganization of production. Compared with the Mexican bank, Indonesia's central bank opts for a less accommodative monetary policy by relaxing interest rates in order to encourage investment, especially in the manufacturing sector, and thus diversify its economy. As far as Argentina is concerned, it still behaves like an importing country. Indeed, the response of the Argentine economy has declined systematically when prices rise which is contrary to our expectations. The country also appears to benefit from lower prices, which have a positive impact on economic activity. This exporting country, whose wealth does not depend primarily on the income generated from the export of crude oil, appears to be "hit" by a supply shock that increases production costs. The central bank tightens its monetary positioning by raising the interest rate with the variable of positive price movements and releasing it somewhat in the presence of the variable of negative movements.

On the side of the importing countries, with the exception of the Czech Republic, the fall in oil prices also has a positive effect on industrial production of these countries, which however decreased when prices increase. Turkey and India remain the most affected and to a lesser 
extent Tunisia ${ }^{13}$ and South Korea.

For the reaction of interest rates, all importing countries show a positive interest rate response in the case of price increases and a negative response in the case of declines. The reaction is more important in the case of South Korea and Turkey. For Tunisia, the reaction of the monetary authorities is more accommodating, however the interest rate values are very low or quasi-nil. The Czech Republic's answer does not really confirm the theoretical predictions because a net increase in prices does not cause a significant and lasting contraction in economic activity. Indeed, the immediate impact of the oil price shock is positive. This result is not very obvious to interpret it but it may be linked to a decrease in energy dependence in this small European and an improvement in energy efficiency during the period. The Czech central bank opts in both configurations for a less accommodative monetary policy with a rise in interest rates that seems very ephemeral.

\subsubsection{Analysis of the Long-term Dynamics}

It should be noted that the negative impact of positive oil price movements is wider than declines and is also higher compared to models estimated with simple price fluctuations and volatility. In fact, the rise in prices reduces significantly economic activity, in contrast to the fall in prices, which shows insignificant coefficients for most of the countries studied. In addition, an asymmetric link between oil prices and the economy has been observed for all emerging countries, but to varying degrees. Substantial price declines did not envisage a warming of economic activity in the oil-consuming countries.

This impact is very clear for the majority of oil importing countries with the exception of the Czech Republic for which the relationship is significantly positive. Contrary to the short-term relationship, this country appears to benefit from a fall in prices over the long term. The decline in oil prices operates in three distinct ways on this European country importing oil. First, when prices are relaxing, the purchasing power of households improves as a result of the improvement in their incomes, which is causing a shift in demand. Second, there is a reduction in the costs of producing finished products, which generates profits for businesses and investors. Third, reducing the costs of production push producers to increase production. As a result, prices will be narrowing, leading to lower inflation. In normal circumstances, the monetary policy of the Czech central bank should react to this decline in inflation by a more than proportional decrease in its real interest rate. This is consistent with the result we found, the coefficient associated with the interest rate is very low which is actually close to $0.08 \%$. We note that Tunisia and Korea are the least affected countries by the net rise in oil prices. It seems that Korea is more affected by the rise in prices compared to Tunisia, showing the weakest upward resistance of oil prices in the Korean industry. For the interest rate variable, we found that the monetary authorities of both countries raise interest rates when the price of oil rises. The rise in oil prices threatens price stability by creating an inflation risk that can certainly occur during the relaxation.

\footnotetext{
${ }^{13}$ Tunisia, which has benefited in the short term from a shock of price volatility and their variation, has nevertheless disadvantaged the positive evolution of oil prices. The impact went from $-0.35 \%$ on the 6 th period to $-0.37 \%$ at the end of the period.
} 
For the other net oil importing economies, the result confirms the status observed in the previous case (volatility and price change). Turkey and India show the weakest resistance to rising oil prices. India seems to be even more penalized in comparison with Turkey, which confirms a strong dependence on oil in this country. The impact is quite asymmetrical: if the rise in prices contracts activity, the decline does not cause its expansion. The result seems logical because the two countries depend heavily on energy. Electricity from these two economies is more widely produced from oil and gas (nearly half for India).

As for the interest rate variable, it is significantly and negatively correlated with industrial production in both countries and in both models. Indeed, to ensure an environment of price stability, the monetary authorities tighten their monetary policy. Even in the event of lower prices, the implementation of a restrictive monetary policy seems more likely given the effects of economic expansion due to the resuscitation of domestic demand. Indeed, in the short term, the fall in oil prices generates a revival of domestic demand generating inflation, even in the long term. For the exporting countries, they behave like an importing country, with the exception of Indonesia, which seems to benefit from price increases like two previous oil price indicators. Indonesian central bank has accommodative monetary policy, in the two cases of the net increase and the net decline in oil prices. Indeed, exporting countries include an importing country to the exclusion of Indonesia, which seems to benefit from the price increase as the previous case of two indicators of oil prices. The Indonesian central bank practices an accommodative monetary policy in both positive and negative variations.

Let us now talk about the two countries of Latin America. The rise in oil prices impacted significantly and negatively the industrial productivity of Mexico and Argentina with a rate of $0.42 \%$ and $0.38 \%$ respectively, while a price decreases have no significant effect. According to several economists, an increase in oil prices favors exploration and extraction of crude oil in exporting countries, but production is likely to react with a long delay (see, for example, Favero, Pesaran and Sharma (1994)). Productivity spillovers between the oil sector and the rest of sectors could lead to an increase in oil production in response to demand-driven oil price shocks (Bjornland and Thorsrud (2013). The effect will depend firstly on the size of the oil sector in the country's total GDP, as well as productivity spillovers between the oil industry and non-oil industries. According to Warner (1995), Bergevin (2006), Mordi and A. Adebiyi (2010), the problem for an exporting country, that due to a misallocation of factors of production, oil revenues are not allocated to investments the most productive in economics.

Table 14. Estimation of the long-term block in the asymmetric case

\begin{tabular}{|c|c|c|c|c|c|c|c|c|}
\hline & Mexico & Indonesia & Argentina & Turkey & $\begin{array}{l}\text { Czech Republic } \\
\text { Republic }\end{array}$ & Tunisia & India & $\begin{array}{l}\text { South } \\
\text { Korea } \\
\end{array}$ \\
\hline Oil+(-1) & $\begin{array}{l}\mathbf{- 0 , 4 2 9 0 1} * * * \\
{[0,05667]}\end{array}$ & $\begin{array}{l}\mathbf{0 , 5 6 3 1 9} * * * \\
{[0,16134]} \\
\end{array}$ & $\begin{array}{l}-\mathbf{0 , 3 8 2 3 9 0} * * * \\
{[0,13465]}\end{array}$ & $\begin{array}{l}\mathbf{- 0 , 5 3 6 0 7 2} * * \\
{[0,05468]} \\
\end{array}$ & $\begin{array}{l}\mathbf{- 0 , 2 6 0 4 8} * * * \\
{[0,05890]} \\
\end{array}$ & $\begin{array}{l}\mathbf{- 0 , 2 9 6 2 5} * * * \\
{[0,05948]} \\
\end{array}$ & $\begin{array}{l}\mathbf{- 0 , 5 9 9 3 1 9} * * \\
{[0,23832]} \\
\end{array}$ & $\begin{array}{l}-\mathbf{0 , 3 7 5 7 6} * * * \\
{[0,07675]} \\
\end{array}$ \\
\hline Oil-(-1) & $\begin{array}{l}0,189575 \\
{[0,19168]}\end{array}$ & $\begin{array}{l}\mathbf{- 0 , 2 0 5 6 4} * * * \\
{[0,05703]}\end{array}$ & $\begin{array}{l}\mathbf{0 , 1 3 9 4 8 3} * * \\
{[0,05572]}\end{array}$ & $\begin{array}{l}0,139532 \\
{[0,62992]}\end{array}$ & $\begin{array}{l}\mathbf{0 , 1 7 1 3 6} * * * \\
{[0,02548]} \\
\end{array}$ & $\begin{array}{l}\mathbf{0 , 0 7 7 6 3 9} * * \\
{[0,04099]} \\
\end{array}$ & $\begin{array}{l}0,148559 \\
{[0,19898]}\end{array}$ & $\begin{array}{l}0,167586 \\
{[0,16104]}\end{array}$ \\
\hline $\operatorname{Ir}(-1)$ & $\begin{array}{l}-\mathbf{0 , 2 9 8 8 7} * * * \\
{[0,05096]}\end{array}$ & $\begin{array}{l}-\mathbf{0 , 0 9 3 1 4} * * \\
{[0,03663]}\end{array}$ & $\begin{array}{l}\mathbf{- 0 , 3 1 5 1 3} * * \\
{[0,17496]}\end{array}$ & $\begin{array}{l}\mathbf{- 0 , 3 3 0 5 2 3} \\
{[0,06317]}\end{array}$ & $\begin{array}{l}\mathbf{- 0 , 0 7 5 8 6} * * * * \\
{[0,02548]}\end{array}$ & $\begin{array}{l}-\mathbf{0 , 2 6 1 0} * * \\
{[0,09663]}\end{array}$ & $\begin{array}{l}\mathbf{- 0 , 4 4 1 6 2 1} * * * \\
{[0,04937]}\end{array}$ & $\begin{array}{l}-\mathbf{0 , 3 0 7 1 5} * * * \\
{[0,06283]}\end{array}$ \\
\hline
\end{tabular}

$*, * *, * * *$ indicate the level of significance at $1 \%, 5 \%, 10 \%$.

The values in braces represent the standard deviations of the coefficients. 


\section{MInstitute Macrothink $_{\text {Int }}$}

The distinction between positive and negative movements in oil prices makes it possible to find a negative and significant effect of rising prices on economic activity for most countries. Negative changes have no significant impact on production. This impact is even not significant for most emerging economies, but clearly suggests an asymmetry in the magnitude of energy price effects on activity. The main conclusion of our empirical work is that the two oil shocks have an unfavorable long-term impact on the economic activity of most emerging countries. Thus the proof of asymmetry is verified: the rise in prices reduces production while the decrease in oil prices does not stimulate growth of the same magnitude.

\section{Conclusion}

The results of the different estimates made with each indicator of oil prices show that the industrial production, the "proxy" variable of the economic activity, is negatively affected by an oil shock. However, this impact is very important with the measurement of price volatility, which is also an indicator of uncertainty. The result also shows that this impact dissipates in the short term to persist in the long term for most countries.

The result reading does not make a clear distinction between exporting and importing countries. Thus, the simplest theoretical intuitions about the difference in response between an exporting country and an importing country are not verified. We therefore find that Argentina behaves differently than Mexico and Indonesia, while Tunisia and to a large extent the Czech Republic stand out from other importing countries. Argentina tends to get closer and behave the sort of these countries. Nevertheless, in the long term, Mexico behaves like an importing country.

The study of the asymmetrical relationship shows a non-linearity in the oil price and activity relationship. We also find that net increases in oil prices have a more significant effect on output than declines. In addition, and in accordance with previous results in the literature, (Hamilton, 2003, Hamilton, 2011, ThankGod Maxwell, 2013), we also found that in the case of an oil exporting country (Mexico and Argentina) oil shocks have asymmetrical effects on output growth. The notable contraction of economic activity in the case of crude oil price increases is not rewarded in the event of declines. Thus, the recessive effect of soaring prices is not equivalent to the beneficial effect of its collapse.

In the end, the reaction of monetary policy seems different in the short term, but it is identical in the long term by indicating a preference of different economies targeting and not targeting to practice a restrictive monetary policy even in the case of price reductions. We found that even in non-targeting economies (India, Tunisia, Argentina), which have not yet explicitly adopted such an inflation-targeting monetary policy framework, they implicitly adapted it to as an alternative nominal anchor for their monetary policy. This also confirms a concern to fight against inflation and a major concern to the control of the price evolution in these countries.

However, the study of the interest rate response has given some insights into the monetary reaction. Indeed, we did not examine in detail the behavior of the monetary authorities in the case of an oil shock through the estimation of a specific reaction function such as the famous 
Taylor rule.

\section{References}

Banihashem, M. A. (2012). Asymmetric Effects of Oil Price Shocks on Economic Growth of Oil-Exporting Countries. USAEE Working Paper, 140(12), Social Science Research Network. [Online] Available: https://onlinelibrary.wiley.com/doi/abs/10.1111/opec.12050

Ben, H. A., Dakhlaoui, A., \& Abbassi, A. (2014). Analysis of the Decomposition of Energy Intensity in Tunisia. International Journal of Energy Economics and Policy, 4(3), 420-426. Retrieved from: https:// www.econjournals.com/index.php/ijeep.

Bergevin, P. H. (2006). Energy Resources: Boon or Curse for the Canadian Economy. Ottawa: Parliamentary Information and Research Service. Library of Parliament. Retrived from: https://publications.gc.ca/pub?id=9.560729\&sl=0

Bjornland, H. C., \& Leif, A. T. (2013). Boom or gloom? Examining the Dutch disease in a two-speed economy. CAMP Working Paper Series, 6. https://doi.org/10.2139/ssrn.2365061

Blanchard, O. J., \& Jordin, G. (2007). The Macroeconomic Effects of Oil Shocks: Why are the 2000s So Different from the 1970s?. NBER Working Paper13368 mimeo. MIT and CREI. https://doi.org/10.3386/w13368

Campan, E., \& Grimaud, A. (1989). Le syndrome hollandais. Revue d'Economie Politique, 99(6), 810-834. [Online] Available: https:// www.jstor.org/stable/i24699084

Engle, R. F. (1982). Autoregressive Conditional Heteroscedasticity with Estimates of the Variance of United Kingdom Inflation. Econometrica, 50, 987-1007.

https://doi.org/10.2307/1912773

Favero, C., Pesaran, M., \& Sharma, S. (1994). A Duration Model of Irreversible Oil Investment: Theory and Empirical Evidence. Journal of Applied Econometrics, 9, 95-112. https://doi.org/10.1002/jae.3950090506

Ftiti, Z., Aviral, T., \& Fatnassi, I. (2014). Oil price and Macroeconomy in India: An evolutionary cospectral coherence approach. IPAG Business School, Working Paper- 068. [Online] Available: https://www.ipag.fr/fr/accueil/la-recherche/publictions-WP.html

Hammadache, A. (2011). Modélisation de prix de pétrole: Analyse avec un Modèle Vectoriel à Correction d'Erreur. CEPN, Centre d'Economie de l'Université Paris-Nord, CNRS, $\mathrm{n}^{\circ}$ 7234. Retrieved from: https://www.docplayer.fr/15738058

Hamilton, J. D. (2003).What is an oil shock?. Journal of Econometrics, 113, 363-398. https://doi.org/10.1016/S0304-4076(02)00207-5

Hamilton, J. D. (2011). Nonlinearities and the Macroeconomic Effects of Oil Prices. Macroeconomic Dynamics, 15, 364-378. https://doi.org/10.1017/S1365100511000307

Johansen, S. (1991). Estimation and Hypothesis Testing of Cointegration Vectors in Gaussian Vector Autoregressive Models. Econometrica, 59(6), 1551-1580. 
https://doi.org/10.2307/2938278

Mehrara, M., \& Oskui, N. K. (2006). The Sources of Macroeconomic Fluctuations in Oil Exporting Countries: A Comparative Study. Economic Modelling, 24, 365-379.

https://doi.org/10.1016/j.econmod.2006.08.005

Mordi, C., \& Adebiyi, A. (2010). The Asymmetric Effects of Oil Price Shocks on Output and Prices in Nigeria using a Structural VAR Model. Central Bank of Nigeria, Economic and Financial Review, 48(1). Retrived from: https://www.semanticscholar.org/paper

Mork, K. A. (1989). Oil and the Macroeconomy When Prices Go Up and Down: An Extension of Hamilton's Results. Journal of Political Economy, 91, 740-744.

https://doi.org/10.1086/261625

Sen, A., \& Sen, A. (2016). India's Oil Demand: On the Verge of 'Take-Off'?. Oxford Institute for Energy Studies, ISBN 978-1-78467-053-5. https://doi.org/10.26889/9781784670535

Sungjee, K. (2011). Market Structure of the Petroleum Industry in South Korea. Energy Economics and Policy, 3(4), 36-55. https://www.files.ethz.ch/cepe/2011TermPapers/p76

ThankGod, A. O., \& Maxwell, I. A. (2013). Macroeconomic Impact of Oil Price Levels and Volatility in Nigeria. International Journal of Academic Research in Economics and Management Sciences, 2(4), 15-25. https://doi.org/10.6007/IJAREMS/v2-i4/48

Warner, A. (1995). Natural Resource Abundance and Economic Growth. NBER working paper, n 5398. https://doi.org/10.3386/w5398

\section{Glossary}

EIU: a British company owned by The Economist Group. Through research and analysis, EIU provides forecasts and advice to its clients. It provides countries, industries and businesses with global analyzes.

IEA: an international organization founded at the OECD in 1974, based in Paris.

Repsol S.A.: a Spanish joint-stock company, founded in October 19873. It focuses on the exploration, production, transport and refining of oil and natural gas.

Eurostat: a Directorate General of the European Commission responsible for statistical information at Community level. 


\section{Appendix}

Appendix 1. The results of the test of Phillips Perron

Table.1. Phillips Perron test in level in the case of the variation of oil prices

\begin{tabular}{|l|l|l|l|l|l|l|l|l|l|}
\hline & Mexico & Argentina & India & South korea & Indonesia & Tunisia & Czech Republic & Turkey & C.V at 1\%,5\%,10\% \\
\hline IPI & $-1,7188$ & $-2,1980$ & $-1,2342$ & $-2,4722$ & $-1,9560$ & $-2,4742$ & $-1,9271$ & $-0,8878$ & $-2,872857$ \\
\hline IR & $-1,5770$ & $-1,61126$ & $-1,4057$ & $-1,6969$ & $-2,2287$ & $-1,8959$ & $-1,6770$ & $-2,5107$ & $-2,872857$ \\
\hline & & & & & & & & & \\
\hline OIL & $-0,9733$ & $-1,0170$ & $-0,8972$ & $-0,9733$ & $-0,8281$ & $-0,1725$ & $-0,2126$ & $-2,572875$ \\
\hline
\end{tabular}

$*, * *, * * *$ indicate the level of significance at $1 \%, 5 \%, 10 \%$.

The values in braces represent the standard deviations of the coefficients.

Table 2. Phillips Perron test in first difference in the case of the variation of the oil prices

\begin{tabular}{|l|l|l|l|l|l|l|l|l|l|}
\hline & Mexico & Argentina & India & South korea & Indonesia & Tunisia & Czech Republic & Turkey & $\begin{array}{l}\text { C.V at } \\
\mathbf{1 \% , 5 \% , 1 0 \%}\end{array}$ \\
\hline IPI & $-34,3588$ & $-16,2454$ & $-19,0623$ & $-28,9216$ & $-19,2295$ & $-15,6066$ & $-16,2189$ & $-17,4188$ & $-2,872904$ \\
\hline IR & $-18,1546$ & $-15,8334$ & $-15,4057$ & $-23,6977$ & $-26,1968$ & $-184,448$ & $-18,6674$ & $-17,0279$ & $-2,872904$ \\
\hline OIL & $-15,4607$ & $-12,1256$ & $-111,335$ & $-12,3451$ & $-30,0192$ & $-7,9922$ & $-22,2537$ & $-24,3254$ & $-2,572,872904$ \\
\hline
\end{tabular}

$*, * *, * * *$ indicate the level of significance at $1 \%, 5 \%, 10 \%$.

The values in braces represent the standard deviations of the coefficients

Table 3. Phillips Perron test level in the case of volatility of oil prices

\begin{tabular}{|l|l|l|l|l|l|l|l|l|l|}
\hline & Mexico & Argentina & India & South korea & Indonesia & Tunisia & Czech Republic & Turkey & C.V at 1\%,5\%,10\% \\
\hline IPI & $-1,7188$ & $-2,1980$ & $-1,2342$ & $-2,4722$ & $-1,9560$ & $-2,4742$ & $-1,9271$ & $-0,8878$ & $-2,872857$ \\
\hline IR & $-1,5770$ & $-1,61126$ & $-1,4057$ & $-1,6969$ & $-2,2287$ & $-1,8959$ & $-1,6770$ & $-2,572875$ \\
\hline
\end{tabular}

$*, * *, * * *$ indicate the level of significance at $1 \%, 5 \%, 10 \%$.

The values in braces represent the standard deviations of the coefficients. 
Table 4. Phillips Perron test in first difference in the case of the volatility of oil prices

\begin{tabular}{|l|l|l|l|l|l|l|l|l|l|}
\hline & Mexico & Argentina & India & South korea & Indonesia & Tunisia & Czech Republic & Turkey & $\begin{array}{l}\text { C.V at } \\
\mathbf{1 \%}, \mathbf{5 \%}, \mathbf{1 0 \%}\end{array}$ \\
\hline IPI & $-34,3588$ & $-16,2454$ & $-19,0623$ & $-28,9216$ & $-19,2295$ & $-15,6066$ & $-16,2189$ & $-17,4188$ & $-3,456408$ \\
$-2,872904$ \\
IR
\end{tabular}

$*, * *, * * *$ indicate the level of significance at $1 \%, 5 \%, 10 \%$

The values in braces represent the standard deviations of the coefficients.

Table 5. Phillips Perron test in first difference in the case of the volatility of oil prices

\begin{tabular}{|l|l|l|l|l|l|l|l|l|l|}
\hline & Mexico & Argentina & India & South korea & Indonesia & Tunisia & Czech Republic & Turkey & $\begin{array}{l}\text { C.V at } \\
\mathbf{1 \% , 5 \% , 1 0 \%}\end{array}$ \\
\hline IPI & $-1,7188$ & $-2,1980$ & $-1,2342$ & $-2,4722$ & $-1,9560$ & $-2,4742$ & $-1,9271$ & $-0,8878$ & $-2,872857$ \\
\hline IR & $-1,5770$ & $-1,61126$ & $-1,4057$ & $-1,6969$ & $-2,2287$ & $-1,8959$ & $-1,6770$ & $-2,5107$ & $-2,872857$ \\
\hline OILPOS & $-1,41861$ & $-0,4040$ & $-1,5852$ & $-1,5306$ & $-1,8417$ & $-2,5391$ & $-1,8186$ & $-2,572875$ \\
\hline
\end{tabular}

$*, * *, * * *$ indicate the level of significance at $1 \%, 5 \%, 10 \%$

The values in braces represent the standard deviations of the coefficients.

Table 6. Phillips Perron test as the first difference in the asymmetric case

\begin{tabular}{|c|c|c|c|c|c|c|c|c|c|}
\hline & Mexico & Argentina & India & South korea & Indonesia & Tunisia & Czech Republic & Turkey & $\begin{array}{l}\text { C.V at } \\
1 \%, 5 \%, 10 \%\end{array}$ \\
\hline IPI & $-34,3588$ & $-16,2454$ & $-19,0623$ & $-28,9216$ & $-19,2295$ & $-15,6066$ & $-16,2189$ & $-17,4188$ & $\begin{array}{c}3,456408 \\
-2,872904 \\
-2,572900\end{array}$ \\
\hline IR & $-18,1546$ & $-15,8334$ & $-15,4057$ & $-23,6977$ & $-26,1968$ & $-184,448$ & $-18,6674$ & $-17,0279$ & $\begin{array}{c}3,456408 \\
-2,872904 \\
-2,572900 \\
\end{array}$ \\
\hline OILPOS & $-20,1028$ & $-20,0448$ & $-9,8293$ & $-12,3427$ & $-19,0623$ & $-19,0012$ & $-16,9727$ & $-17,9938$ & $\begin{array}{c}3,456408 \\
-2,872904 \\
-2,572900\end{array}$ \\
\hline OILNEG & $-15,6611$ & $-22,8066$ & $-17,4301$ & $-31,8429$ & $-17,1153$ & $-131,126$ & $-18,6633$ & $-21,2599$ & $\begin{array}{l}3,456408 \\
-2,872904 \\
-2,572900\end{array}$ \\
\hline
\end{tabular}

$*, * *, * * *$ indicate the level of significance at $1 \%, 5 \%, 10 \%$. 
The values in braces represent the standard deviations of the coefficients.

Appendix 2. The results of the short-term dynamics

Table 1. Cumulative impacts on the index of industrial production to a shock of the indicator of volatility of oil prices

\begin{tabular}{|l|l|l|l|}
\hline & At 6 month & At 12 month & At 18month \\
\hline Mexico & 0,601092 & 0,601414 & 0,601418 \\
\hline Argentina & $-0,196362$ & $-0,201551$ & $-0,201331$ \\
\hline South korea & $-0,931207$ & $-0,337994$ & $-0,495973$ \\
\hline India & $-0,101281$ & $-0,105221$ & $-0,104561$ \\
\hline Indonesia & 0,333793 & 0,351902 & 0,350948 \\
\hline Tunisia & 0,425751 & 0,437101 & 0,437667 \\
\hline Czech Republic & 0,360886 & 0,365956 & 0,365975 \\
\hline Turkey & $-0,407555$ & $-0,372045$ & $-0,372362$ \\
\hline
\end{tabular}

Table 2. Cumulative impacts on the index of industrial production to a shock of the indicator of changes in oil prices

\begin{tabular}{|l|c|c|l|}
\hline & At 6 month & At 12 month & At 18month \\
\hline Mexico & 0,398043 & 0,447243 & 0,453210 \\
\hline Argentina & $-0,147650$ & $-0,151633$ & $-0,151699$ \\
\hline South korea & $-0,130177$ & $-0,096887$ & $-0,130627$ \\
\hline India & $-0,231752$ & $-0,216180$ & $-0,216127$ \\
\hline Indonesia & 1,164506 & 1,186235 & 1,186635 \\
\hline Tunisia & 0,133339 & 0,133167 & 0,133167 \\
\hline Czech Republic & 0,189700 & 0,189068 & 0,189098 \\
\hline Turkey & 0,018447 & 0,018735 & 0,018798 \\
\hline
\end{tabular}

Table 3. Cumulative impact on the interest rate to a shock of the indicator of the volatility of oil prices

\begin{tabular}{|l|c|c|l|}
\hline & At 6month & At12 month & At 18month \\
\hline Mexico & $-0,012548$ & $-0,011814$ & $-0,011808$ \\
\hline Argentina & 0,121555 & 0,140331 & 0,140415 \\
\hline South korea & 0,507610 & 0,360763 & 0,506758 \\
\hline India & 0,151201 & 0,143952 & 0,144187 \\
\hline Indonesia & $-0,099318$ & $-0,109331$ & $-0,108827$ \\
\hline Tunisia & 0,120223 & 0,120867 & 0,120879 \\
\hline Czech Republic & 1,479967 & 1,503329 & 1,503488 \\
\hline Turkey & $-0,053761$ & $-0,026401$ & $-0,020521$ \\
\hline
\end{tabular}

Table 4. Cumulative impact on the interest rate to a shock of the indicator of changes in oil prices

\begin{tabular}{|l|l|l|l|}
\hline & At 6month & At 12 month & At 18month \\
\hline Mexico & 0,020606 & 0,021779 & 0,022607 \\
\hline Argentina & 0,062366 & 0,064208 & 0,064247 \\
\hline South korea & 0,441975 & 0,428555 & 0,428367 \\
\hline India & 0,255839 & 0,169056 & 0,188774 \\
\hline Indonesia & $-0,016106$ & $-0,012449$ & $-0,012671$ \\
\hline Tunisia & $-0,082702$ & $-0,084644$ & $-0,084606$ \\
\hline Czech Republic & 0,095842 & 0,097528 & 0,097976 \\
\hline Turkey & $-0,052406$ & $-0,077859$ & $-0,075523$ \\
\hline
\end{tabular}


Table 5. Cumulative impacts on the index of industrial production to a shock of the indicator of positive movements in oil prices

\begin{tabular}{|l|l|l|l|}
\hline & At 6month & At 12 month & At 18month \\
\hline Mexico & 2,045716 & 1,887308 & 1,889005 \\
\hline Argentina & $-0,334150$ & $-0,327842$ & $-0,303369$ \\
\hline South korea & $-0,700066$ & $-0,602744$ & $-0,598614$ \\
\hline India & $-1,026232$ & $-0,980262$ & $-0,980593$ \\
\hline Indonesia & 3,728633 & 3,869290 & 3,822324 \\
\hline Tunisia & $-0,355212$ & $-0,368813$ & $-0,375486$ \\
\hline Czech Republic & $-1,977467$ & $-1,696769$ & $-1,705574$ \\
\hline Turkey & 0,328949 & 0,332417 & 0,332989 \\
\hline
\end{tabular}

Table 6. Cumulative impacts on the index of industrial production to a shock of the indicator of negative movements in oil prices

\begin{tabular}{|l|l|l|l|}
\hline & At 6month & At 12 month & At 18month \\
\hline Mexico & 0,040254 & 0,078196 & 0,080137 \\
\hline Argentina & 0,179236 & 0,242897 & 0,242077 \\
\hline South korea & 0,214278 & 0,250475 & 0,246742 \\
\hline India & 1,137784 & 0,953348 & 0,937902 \\
\hline Indonesia & 0,909920 & 1,185206 & 1,224760 \\
\hline Tunisia & 0,388063 & 0,430816 & 0.438877 \\
\hline Czech Republic & 0,423549 & 0,607055 & 0,595074 \\
\hline Turkey & 0,098128 & 0,115809 & 0,118700 \\
\hline
\end{tabular}

Table 7. Cumulative impacts on the interest rate to a shock of the indicator of positive movements in oil prices

\begin{tabular}{|l|l|l|l|}
\hline & At 6month & At 12 month & At 18month \\
\hline Mexico & 2,532256 & 2,550502 & 2,551282 \\
\hline Argentina & 0,248264 & 0,223205 & 0,209975 \\
\hline South korea & 1,152990 & 1,164785 & 1,164753 \\
\hline India & 1,270249 & 1,264990 & 1,262511 \\
\hline Indonesia & $-0,539514$ & $-0,947295$ & $-1,290720$ \\
\hline Tunisia & 0,458153 & 0,539996 & 0,543808 \\
\hline Czech Republic & 1,316232 & 1,380358 & 1,380675 \\
\hline Turkey & 0,075478 & 0,089754 & 0,085467 \\
\hline
\end{tabular}

Table 8. Cumulative impact on the interest rate to a shock of the indicator of negative movements in oil prices

\begin{tabular}{|l|l|l|l|}
\hline & At 6month & At 12 month & At 18month \\
\hline Mexico & 0,222047 & 0,223807 & 0,223633 \\
\hline Argentina & 0,067841 & 0,086381 & 0,083309 \\
\hline South korea & $-0,126149$ & $-0,123673$ & $-0,124292$ \\
\hline India & $-0,215751$ & $-0,174775$ & $-0,171733$ \\
\hline Indonesia & $-0,240037$ & $-0,372816$ & $-0,497664$ \\
\hline Tunisia & $-0,144888$ & $-0,167269$ & $-0,166220$ \\
\hline Czech Republic & $-0,487634$ & $-0,375436$ & $-0,382227$ \\
\hline Turkey & 0,022477 & 0,027860 & 0,028727 \\
\hline
\end{tabular}




\section{Copyright Disclaimer}

Copyright for this article is retained by the author(s), with first publication rights granted to the journal.

This is an open-access article distributed under the terms and conditions of the Creative Commons Attribution license (http://creativecommons.org/licenses/by/3.0/). 